\title{
History of syphilis in women living with AIDS and associated risk factors in São Paulo, Brazil
}

\author{
Valdir Monteiro Pinto ${ }^{1 *}$, Mariza Vono Tancredi $^{1}$, Cassia Maria Buchalla ${ }^{2}$, Angelica Espinosa Miranda ${ }^{3}$ \\ ${ }^{1}$ STD/AIDS Reference and Training Center - State STD and AIDS program of São Paulo - São Paulo State Health Department, São Paulo, Brazil; \\ ${ }^{2}$ Faculty of Public Health at the University of São Paulo - FSP/USP - São Paulo, Brazil; \\ ${ }^{3}$ Department of Social Medicine, Infectious Disease Center, Federal University of Espírito Santo (UFES), Vitória, ES, Brazil.
}

Work conducted at the STD/AIDS Reference and Training Center in São Paulo, São Paulo, SP, Brazil

Article received: 6/25/2013 Accepted for publication: 1/13/2014

*Correspondence: Address: Rua Santa Cruz, 81, São Paulo, SP ZIP Code: 04121-000 Phone: +55 115087.9981 Mobile: +55 1198162.9020 e-mail: vmpinto@usp.br; valdir.pinto@crt. saude.sp.gov.br http://dx.doi.org/10.1590/1806-9282.60.04.013 Conflict of interest: none

\section{SUMmarY}

Objective: to describe the epidemiological profile, risk behaviors, frequency of prior history of syphilis in women living with AIDS and to investigate associated factors. Methods: a cross-sectional study conducted with women living with HIV attending at Reference Center for AIDS in São Paulo. Demographic, behavioral, and clinical data were analyzed based on medical records.

Results: a total of 598 women were included in the study and the prevalence of previous syphilis was $6.2 \%$ (95\% CI 4,3-8,1). Seventy-three percent of women were less than 40 years of age when diagnosed with AIDS and $49.6 \%$ had more than eight years of formal education. $67.2 \%$ were white and $65.9 \%$ were not married or living with a partner, $53.2 \%$ reported that their first sexual intercourse aged more than 15 years, $56.5 \%$ reported having only one partner in the last year and $13 \%$ reported drug use. Regarding laboratory data, $83.8 \%$ had CD $4+<500$ cells/ $\mathrm{mm}^{3}$ upon diagnosis of AIDS. Previous syphilis was associated with the use of crack cocaine $[\mathrm{AOR}=6.8(95 \% \mathrm{CI} 1.7-27.5)],>1$ sexual partner in the last year $[\mathrm{AOR}=6.6(95 \% \mathrm{CI} 1.2-37.1)], \mathrm{CD} 4+<500$ cells $/ \mathrm{mm}^{3}[\mathrm{AOR}=3.8$ (women $1.1-$ 13.6)], HIV diagnosis $>8$ years $[\mathrm{AOR}=2.4(95 \% \mathrm{CI} 1.0-5.8)]$.

Conclusion: a high prevalence of previous syphilis was found in the population studied, and crack use was identified among the main associated risk factors. Interventions to reduce the risk of sexual transmission of HIV and syphilis must be strengthened, with the implementation of control actions, screening strategies, early diagnosis and treatment, preventing complications, reducing morbidity and improving sexual and reproductive health.

Uniterms: syphilis, sexually transmitted diseases (STDs), AIDS, risk behavior, women.

\section{INTRODUCTION}

In 2010, the World Health Organization (WHO) published an estimate of a total of 11 million new cases of syphilis per year worldwide, with 2.4 million in Latin America and the Caribbean. ${ }^{1}$

It has been known for a long time that one of the reasons for the increase in sexually transmitted diseases (STDs) in developing countries is the lack of access to effective and reliable health services. ${ }^{2}$ Demographic factors such as the large number of sexually active young people, multiple sexual partners without the use of condoms, etc. have also contributed to this increase. ${ }^{3}$
Studies have already demonstrated that there is an increased risk of 3 to 10 times of becoming infected with HIV in the presence of an STD, depending on the type and etiology of the STD, 4,5 being syphilis the most common among men and women with HIV. ${ }^{6,7}$ Infection with HIV has already been independently associated with syphilis with more than three times the risk ${ }^{8}$ as well as with a history of syphilis. ${ }^{9}$

In people living with HIV/AIDS (PLWHA) who are also affected by genital ulceration, the viral load in the genital secretions increases, ${ }^{10}$ also considerably increasing infectiousness. ${ }^{11}$ 
The tendencies for HIV and syphilis have shown an increase in western Europe, where the number of PLWHA has increased 10 to $15 \%$ per year since 1996 , and the number of cases of syphilis in women has practically doubled from 1995 to $2000 .^{12}$

In Brazil, where the epidemic has already been responsible for more than 650,000 cases, AIDS has been growing among the female population, meaning that today for every 1.5 cases of AIDS among men there is 1 case of the disease in women. ${ }^{13}$ The percentage of STDs involved in the transmission of HIV is not known, as the majority of women are asymptomatic, including syphilis.

Evidence that syphilis is a biological cofactor in the acquisition and transmission of HIV has already been demonstrated and could contributed to facilitating the dissemination of HIV infection. Therefore, the diagnosis and early treatment of STDs should be part of high quality strategies in the prevention of HIV infection. ${ }^{14}$

This study intends to describe the epidemiological profile, risk behaviors, frequency of prior history of syphilis in women living with AIDS and to investigate the associated risk factors that can be used in the implementation of prevention and care programs for such women.

\section{Methods}

Cross-sectional study conducted by the Sexually Transmitted Diseases and AIDS Reference and Training Center in São Paulo (CRT-DST/AIDS). This center monitors approximately 4,000 people with HIV/AIDS, 1,100 of whom are women.

The data was collected from the medical records of all of the women living with AIDS that had gynecological consultations scheduled in the period from June $1^{\text {st }} 2008$ to May $31^{\text {st }}, 2009$. Social and demographic, behavioral and clinical characteristics, such as age, level of education, marital status, age at the time of first sexual intercourse, number of sexual partners, drug use, HIV diagnosis time, $\mathrm{T}$ $\mathrm{CD} 4+$ lymphocytes and viral load (VL), among others, were selected for analysis.

The study included women using high strength antiretroviral drugs, and excluded those that did not have T CD4+ lymphocyte count and HIV viral load results or did not have the gynecological consultation described.

The reports of prior history of syphilis were noted, as well as the results of laboratory exams in the routine of the service, such as HIV infection time, CD4+ count, VL and serology for syphilis. The race/color variable, which was self-reported, considered black women as those who declared themselves as being black or mixed-race. The level of education and human development index (HDI) were used as indicators of the socioeconomic level owed to the association with various lifestyle characteristics. The data collected from medical records was related with the HDI database of the city of São Paulo in the year 2000, using the deterministic linkage method that makes a nominal identification in two databases.

A prior history of syphilis was considered as a dependent variable for conducting the analysis. The risks for prior history of syphilis were studied for all of the independent variables of interest stated above.

The clinical/epidemiological information and the findings of the results of laboratory exams were codified and stored in a database created for this purpose. The statistics program STATA 10.0 was used for saving and analyzing the data.

The analysis was conducted using exploratory techniques on the data to verify the distribution patterns and tendencies for the main variables. Next, a bivariate analysis was undertaken to verify the presence of an association between them. The chi-squared $\left(c^{2}\right)$ test was used for differences of proportion and the Student's $t$-test and variance analysis for differences between the averages. To estimate associations, the odds ratio was used with a confidence interval of $95 \%$. The variables were selected to compose the model when the likelihood ratio test (LRT) presented a p value equal to or less than 0.25 . A multivariate analysis was undertaken to estimate the joint effects of independent variables through the use of logistic regression models. This model was adjusted using the step forward procedure and the inclusion of variables followed the ascending order of OR values. The importance of the variables for the final model was evaluated using the likelihood ratio test, considering $\mathrm{p}<0.05$.

The project was approved by the Research Ethics Committee at the STD/AIDS Reference and Training Center in São Paulo.

\section{RESULTS}

598 women were included from a total of 710 scheduled for gynecological consultations in the period of the study. 112 (15.8\%) were excluded, including 33 women whose information about the prior history of syphilis was ignored, 29 that did not present prior or current gynecological consultations, 23 who were not using antiretroviral drugs, 18 with a negative serology for HIV, and 9 women living with HIV acquired by vertical transmission and without sexual activity.

The reports of prior history of syphilis represented 37 cases out of 598 women, with an estimated prevalence of $6.2 \%$ (95\% CI: 4.3 - 8.1). 
The social and demographic characteristics of the women are presented in Table 1 . The majority of women were less than 40 years old (73.6\%) at the time of being diagnosed with AIDS and in relation to level of education, $49.6 \%$ of women had completed more than eight years of education. In relation to race, the majority were white $(67.2 \%)$ and more than two thirds $(65.9 \%)$ were not married or living with a partner. It was also noted that more than a third of the women $(35.6 \%)$ lived in a district with a low human development index (HDI).

Table 2 describes the behavioral characteristics of the population studied. More than half of the population (53.2\%) started their sexual life aged over 15 years; $56.5 \%$ of the women reported that they had had only one sexual partner in the last year, while $35.1 \%$ reported six or more partners during their life (data not shown in the table). Around a third of them (29.9\%) had had more than three pregnancies, and $2.7 \%$ of the women declared that they were sex workers (data not show in the table). The use of drugs was reported by $13 \%$ of the women, with almost a quarter of these reporting the use of crack cocaine (23.1\%).

A total of $43.6 \%$ of the women had been diagnosed with HIV infection for nine or more years, with extremes of 1 and 22 years of monitoring time. $83.8 \%$ presented a $\mathrm{T}$ CD4+ lymphocyte count in the AIDS diagnosis below 500 cells $/ \mathrm{mm}^{3}$.

The bivariate analysis of the factors associated with a history of syphilis in women living with AIDS and their risks are described in Table 3. Through the multivariate analysis in the logistic regression model, the factors associated with a history of syphilis infection in women living with AIDS were identified, as presented in Table 4. The factors associated with a history of syphilis and the respective risks were the use of crack cocaine $[\mathrm{AOR}=6.8(95 \% \mathrm{CI} 1.7-27.5)]$, more than one sexual partner in the last year $[\mathrm{AOR}=6.6(95 \% \mathrm{CI}$ 1.2 - 37.1)], T CD4 + lymphocyte count of less than 500 cells/ $\mathrm{mm}^{3}[\mathrm{AOR}=3.8(95 \% \mathrm{CI} 1.1-13.6)]$ and HIV diagnosis for more than 8 years $[\mathrm{AOR}=2.4(95 \% \mathrm{CI} 1.0-5.8)]$.

TABLE 1 Distribution of sociodemographic characteristics of patients with AIDS according to history of syphilis. CRT. 2008 to 2009

\begin{tabular}{|c|c|c|c|c|c|c|c|}
\hline \multirow[t]{3}{*}{ Characteristics } & \multicolumn{4}{|c|}{ Syphilis } & & & \multirow[t]{3}{*}{$\mathbf{p}^{*}$} \\
\hline & \multicolumn{2}{|c|}{ Yes $(n=37)$} & \multicolumn{2}{|c|}{ No $(n=561)$} & \multicolumn{2}{|c|}{ Total (598) } & \\
\hline & $\mathbf{n}$ & $\%$ & n & $\%$ & n & $\%$ & \\
\hline Age range at the time of AIDS & & & & & & & 0.392 \\
\hline$\leq 40$ years & 25 & 67.6 & 415 & 74 & 440 & 73.6 & \\
\hline \multirow[t]{2}{*}{$>40$ years } & 12 & 32.4 & 146 & 26 & 158 & 26.4 & \\
\hline & 37 & 100.0 & 561 & 100.0 & 598 & 100.0 & \\
\hline Education (years of study) & & & & & & & 0.679 \\
\hline None & 1 & 2.7 & 5 & 0.9 & 6 & 1 & \\
\hline 1 to 4 years & 4 & 10.8 & 44 & 7.8 & 48 & 8 & \\
\hline 5 to 8 years & 13 & 35.1 & 229 & 40.8 & 242 & 40.5 & \\
\hline 9 to 11 years & 16 & 43.2 & 206 & 36.7 & 222 & 37.1 & \\
\hline$\geq 12$ years & 3 & 8.1 & 72 & 12.8 & 75 & 12.5 & \\
\hline \multirow[t]{2}{*}{ Ignored } & - & - & 5 & 0.9 & 5 & 0.8 & \\
\hline & 37 & 100.0 & 561 & 100.0 & 598 & 100.0 & \\
\hline Race/color (self-reported) & & & & & & & 0.526 \\
\hline White & 22 & 59.5 & 380 & 67.7 & 402 & 67.2 & \\
\hline Non white & 15 & 40.5 & 179 & 31.9 & 194 & 32.4 & \\
\hline \multirow[t]{2}{*}{ Ignored } & - & - & 2 & 0.4 & 2 & 0.3 & \\
\hline & 37 & 100.0 & 561 & 100.0 & 598 & 100.0 & \\
\hline Marital status & & & & & & & 0.831 \\
\hline Single & 10 & 27 & 155 & 27.6 & 165 & 27.6 & \\
\hline Married/partner & 14 & 37.8 & 190 & 33.9 & 204 & 34.1 & \\
\hline Separated/divorced & 8 & 21.6 & 100.0 & 17.8 & 108 & 18.1 & \\
\hline Widow & 5 & 13.5 & 111 & 19.8 & 116 & 19.4 & \\
\hline \multirow[t]{2}{*}{ Ignored } & - & - & 5 & 0.9 & 5 & 0.8 & \\
\hline & 37 & 100.0 & 561 & 100.0 & 598 & 100.0 & \\
\hline $\mathrm{HDI}$ in the district of residence & & & & & & & 0.607 \\
\hline$>0.550$ & 21 & 56.8 & 364 & 64.9 & 385 & 64.4 & \\
\hline \multirow[t]{2}{*}{$0-0.550$} & 16 & 43.2 & 197 & 35.1 & 213 & 35.6 & \\
\hline & 37 & 100.0 & 561 & 100.0 & 598 & 100.0 & \\
\hline
\end{tabular}

CRT: Centro de Referência e Treinamento em DST/Aids de São Paulo. * Pearson's test 
TABLE 2 Distribution of behavioral characteristics of women living with AIDS according to history of syphilis. CRT. 2008 to 2009

\begin{tabular}{|c|c|c|c|c|c|c|c|}
\hline \multirow[t]{3}{*}{ Characteristics } & \multicolumn{4}{|c|}{ Syphilis } & & & \multirow[t]{3}{*}{$\mathbf{p}^{*}$} \\
\hline & \multicolumn{2}{|c|}{ Yes $(n=37)$} & \multicolumn{2}{|c|}{ No $(n=561)$} & \multicolumn{2}{|c|}{ Total (598) } & \\
\hline & $\mathbf{n}$ & $\%$ & $\mathrm{n}$ & $\%$ & $\mathrm{n}$ & $\%$ & \\
\hline Age at first coitus & & & & & & & 0.014 \\
\hline$\leq 15$ years & 22 & 59.5 & 201 & 35.8 & 223 & 37.3 & \\
\hline$>15$ years & 12 & 32.4 & 306 & 54.5 & 318 & 53.2 & \\
\hline Ignored & 3 & 8.1 & 54 & 9.6 & 57 & 9.5 & \\
\hline No. of partners in the past year & & & & & & & $<0.001$ \\
\hline None & 13 & 35.1 & 202 & 36 & 215 & 36 & \\
\hline Single & 15 & 40.5 & 323 & 57.6 & 338 & 56.5 & \\
\hline 2 to 5 & 4 & 10.8 & 14 & 2.5 & 18 & 3 & \\
\hline More than 5 & 2 & 5.4 & 1 & 0.2 & 3 & 0.5 & \\
\hline Ignored & 3 & 8.1 & 21 & 3.7 & 24 & 4 & \\
\hline Use of drugs & & & & & & & $<0.001$ \\
\hline Does not use & 26 & 70.3 & 491 & 87.5 & 517 & 86.5 & \\
\hline Crack & 6 & 16.2 & 12 & 2.1 & 18 & 3 & \\
\hline Other drugs & 5 & 13.5 & 55 & 9.8 & 60 & 10 & \\
\hline Ignored & & - & 3 & 0.5 & 3 & 0.5 & \\
\hline Time of HIV diagnosis (years) & & & & & & & 0.002 \\
\hline 1 to 8 years & 12 & 32.4 & 325 & 57.9 & 337 & 56.4 & \\
\hline$\geq 9$ years & 25 & 67.6 & 236 & 42.1 & 261 & 43.6 & \\
\hline CD4 at AIDS diagnosis (cell/mm³) & & & & & & & $<0.001$ \\
\hline$>500$ & 4 & 10.8 & 93 & 16.6 & 97 & 16.2 & \\
\hline $350-500$ & 30 & 81.1 & 214 & 38.1 & 244 & 40.8 & \\
\hline$<350$ & 3 & 8.1 & 254 & 45.3 & 257 & 43 & \\
\hline Number of pregnancies & & & & & & & 0.01 \\
\hline 0 to 3 & 19 & 51.4 & 400 & 71.3 & 419 & 70.1 & \\
\hline More than 3 & 18 & 48.6 & 161 & 28.7 & 179 & 29.9 & \\
\hline
\end{tabular}

* Pearson's test

TABLE 3 Bivariate analysis of factors associated with syphilis in women living with AIDS, CRT-DST/AIDS. 2008 and 2009

\begin{tabular}{|c|c|c|c|}
\hline \multicolumn{4}{|c|}{ Characteristics of users } \\
\hline & OR cr & 95\%Cl (ORcr) & $\mathbf{p}$ \\
\hline \multicolumn{4}{|c|}{ Age at first coitus } \\
\hline$\leq 15$ years & 1 & - & - \\
\hline$>15$ years & 2.8 & 1.3 to 5.8 & 0.006 \\
\hline Ignored & 1.4 & 0.4 to 5.2 & 0.599 \\
\hline \multicolumn{4}{|c|}{ No. of partners in the past year } \\
\hline None & 1 & - & - \\
\hline Single & 0.7 & 0.3 to 1.5 & 0.402 \\
\hline 2 to 5 & 4.4 & 1.3 to 15.4 & 0.019 \\
\hline More than 5 & 31.1 & 2.6 to 365.6 & 0.006 \\
\hline \multicolumn{4}{|l|}{ Ignored } \\
\hline \multicolumn{4}{|l|}{ Use of drugs } \\
\hline Does not use & 1 & - & - \\
\hline Crack & 9.4 & 3.3 to 27.1 & $<0.001$ \\
\hline Other drugs & 1.7 & 0.6 to 4.6 & 0.288 \\
\hline \multicolumn{4}{|l|}{ Ignored } \\
\hline \multicolumn{4}{|c|}{ Time of HIV diagnosis (years) } \\
\hline 1 to 8 years & 1 & - & - \\
\hline$\geq 9$ years & 2.9 & 1.4 to 5.8 & 0.004 \\
\hline \multicolumn{4}{|c|}{ CD4 at AIDS diagnosis (cell/mm ${ }^{3}$ ) } \\
\hline$>500$ & 1 & - & - \\
\hline $350-500$ & 3.3 & 1.1 to 9.5 & 0.031 \\
\hline$<350$ & 0.3 & 0.1 to 1.2 & 0.095 \\
\hline \multicolumn{4}{|c|}{ Number of pregnancies } \\
\hline 0 to 3 & 1 & - & - \\
\hline More than 3 & 2.3 & 1.2 to 4.6 & 0.012 \\
\hline
\end{tabular}

OR br: Odds ratio gross.

95Cl: Confidence Interval of 95\%. 
TABLE 4 Multivariate analysis of factors associated with syphilis in women living with AIDS. CRT-DST/AIDS, 2008 and 2009

\begin{tabular}{|c|c|c|c|}
\hline Characteristics of users & $\mathrm{OR}_{\mathrm{aj}}$ & 95\% Cl (OR aj) & $\mathbf{p}$ \\
\hline \multicolumn{4}{|c|}{ Time of HIV diagnosis (years) } \\
\hline 1 to 8 & 1 & - & - \\
\hline$\geq 9$ years & 2.4 & 1.0 to 5.8 & 0.046 \\
\hline \multicolumn{4}{|c|}{ No. of partners in the past year } \\
\hline None & 1 & - & - \\
\hline Single & 0.6 & 0.2 to 1.3 & 0.201 \\
\hline 2 to 5 & 6.6 & 1.2 to 37.1 & 0.032 \\
\hline
\end{tabular}

CD4 at AIDS diagnosis (cell/ $\mathrm{mm}^{3}$ )

\begin{tabular}{l|l|c|c}
\hline$>500$ & 1 & - & - \\
\hline $350-500$ & 3.8 & 1.1 to 13.6 & 0.040 \\
\hline
\end{tabular}

Use of drugs

\begin{tabular}{l|l|l|c}
\hline Does not use & 1 & \multicolumn{1}{|c}{-} & - \\
\hline Crack & 6.8 & 1.7 to 27.5 & 0.007 \\
\hline Other drugs & 0.7 & 0.2 to 2.7 & 0.573 \\
\hline
\end{tabular}

OR aj: Odds ratio adjusted.

95Cl: Confidence Interval of $95 \%$.

\section{Discussion}

This study intended to describe the epidemiological profile, risk behavior and frequency of the prior history of syphilis in women living with AIDS cared for by the STD/AIDS Reference Center in São Paulo. A high prevalence of prior history of syphilis was found in the population studied.

Despite having adequate diagnostic methods and simple treatment, syphilis remains an important public health problem worldwide. In Brazil, there are few studies available analyzing the prevalence of syphilis in people living with HIV/AIDS (PLWHA).

In a study conducted in Pernambuco ${ }^{15}$ with 399 PLWHA, 25\% being female, syphilis was the most frequent sexually transmitted disease encountered, with a prevalence of $8.8 \%$, as well as a study in Paraná, ${ }^{16}$ with a sample of $44.1 \%$ of women, which found a $14.3 \%$ prevalence of syphilis. However, both studies failed to describe the exclusive rate among women. Another study of pregnant women infected with HIV in Bahia, ${ }^{17}$ also found a high prevalence of syphilis $(9.5 \%)$.

Reports of a prior history of syphilis were observed in $6.2 \%$ of our sample, a higher rate than that found by Saxton et al. ${ }^{18}$ in women living with HIV/AIDS in the Ukraine (1.9\%). However, the lower age of the population being studied should be taken into account. Our rate was lower than the $11.5 \%$ found by Robertson et al., in the USA, where a history of syphilis among women living with HIV/AIDS presented an increased risk of infection by HIV of 2.8. ${ }^{19}$ The rate is also lower than the findings of Signorini et al., ${ }^{20}$ in Rio de Janeiro, which found a rate of $15.3 \%$ of syphilis, considering any concentration of VDRL and active diseases was defined only for concentrations $\geq 01: 16 \mathrm{AM}$, with a prevalence of $2.7 \%$, with $1.1 \%$ among women, as well as Callegari et al., ${ }^{21}$ in Espírito Santo with prior history of syphilis in $18.9 \%$ of a population of PLWHA, where $45 \%$ were women.

In our study, the prior history of syphilis was significantly associated with the use of crack cocaine, more than one sexual partner in the last year, a CD4+ count below 500 cells $/ \mathrm{mm}^{3}$ and an HIV infection diagnosis time of more than eight years.

In relation to the use of crack cocaine, the results of this study are corroborated by other research conducted in the United States. ${ }^{19,22,23}$ A study conducted in Jamaica also identified an association between syphilis and HIV infection, with the prevalence of the use of crack/cocaine in PLWHA was $8 \%$, which is higher than that identified in our investigation (3\%). However, the authors did not present the percentage for the use of crack alone, or exclusively among women. ${ }^{24}$ In a study by Hwang et al. syphilis was strongly associated with HIV infection, and the majority of injecting drug users (IDUs) is also crack users. However, in the study the use of crack disappeared when adjusted for IDUs. ${ }^{25}$

A single sexual partner in the last 12 months was shown to be a protection factor for syphilis in women living with AIDS in our study, and it was identified that the more sexual partners, the higher the risk, suggesting a dose-response effect. Fonseca and Bastos ${ }^{26}$ analyzed the AIDS epidemic in Brazil and identified that among women the dynamic occurs, for the most part, owed to multiple sexual partners, or partners with multiple sexual partners.

Our findings have shown an association between a prior history of syphilis and a reduction in CD4+ levels, in accordance with the study by Buchacz et al., ${ }^{27}$ which demonstrated that syphilis is associated with an increase in the HIV viral load and significant reduction in CD4 lymphocytes, as well as Kofoed et $\mathrm{al},{ }^{28}$ who identified a reduction in $\mathrm{CD} 4$ during the course of syphilis infection.

In the same manner, in Brazil, Travassos et al., ${ }^{17}$ found an association between a CD 4 count below 500 cells $/ \mathrm{mm}^{3}$ with the presence of STDs in women living with HIV. The fact that their analysis did not specify the STDs in isolation, and considering that syphilis presented the second highest prevalence among bacterial STDs, this may have contributed strongly to this association. 
The use of retrospective data is one of the limits to this study. However, the good quality of the data in the medical records and the low rate of information loss have reduced this limitation.

In a recent publication systematically reviewing the prevalence of STDs in PLWHA, Kalichman et al., identified syphilis as the most common STD in this population, with an average prevalence of $9.5 \%$ in 37 studies. $^{29}$

In our study, the level of prior history of syphilis in women living with AIDS was high (6.2\%), and the associated risk factors were the use of crack cocaine, having more than two sexual partners in the preceding year, a CD4+ count between 350 and 500 cells $/ \mathrm{mm}^{3}$ and HIV diagnosis time of over eight years.

Healthcare services are not always ready to deal with the different constraints experienced by women in exercising their sexuality, which impedes the incorporation of protective practices and increases their vulnerability to STDs and HIV. ${ }^{30}$ Therefore, there is still much work to be undertaken in order to identify innovative interventions relating to the social, cultural and environmental influences on the presence of STDs in this group. There is also a need to find better means of access for the prevention of HIV, so that effective interventions can be more widely used.

Sexually active women need confidential and welcoming services to teach them how to protect themselves from diseases, including sexually transmitted ones which may be asymptomatic in the majority of females, and therefore subject to complications caused by non-treatment.

As syphilis is among the most well established risk factors for the acquisition of HIV, public health programs should be reinforced with the implementation of control actions. Tracking, diagnosis and early treatment actions can help to avoid complications, reduce morbidity with improved sexual and reproductive health of the population.

\section{Resumo}

Antecedentes de sífilis em mulheres com Aids e fatores de risco associados, São Paulo, Brasil.

Objetivo: descrição de perfil epidemiológico, comportamentos de risco, frequência de antecedentes de sífilis em mulheres com Aids e investigar fatores associados.

Métodos: estudo de corte transversal conduzido com mulheres com HIV/Aids atendidas em centro de referência para Aids em São Paulo. Dados demográficos, comportamentais e clínicos foram analisados a partir dos prontuários médicos.
Resultados: foram incluídas 598 mulheres no estudo e a prevalência de antecedentes de sífilis foi 6,2\% (IC 95\%: $4,3$ a 8,1$)$. Um total de $73 \%$ das mulheres tinha menos de 40 anos de idade na época do diagnóstico da Aids e 49,6\% alcançaram mais de 8 anos de escolaridade, sendo que $67,2 \%$ eram brancas e $65,9 \%$ não eram casadas nem viviam com parceiro, $53,2 \%$ alegaram primeiro coito com mais de 15 anos de idade, 56,5\% referiram apenas um parceiro no último ano, $13 \%$ referiram uso de drogas e $83,8 \%$ apresentavam CD4+ $<500$ cél $/ \mathrm{mm}^{3}$ no diagnóstico da Aids. Foram fatores associados à infecção por sífilis: uso de $\operatorname{crack}\left[\mathrm{OR}_{\mathrm{aj}}=6,8\right.$ (IC 95\% 1,7 - 27,5)], mais de 1 parceiro sexual no último ano $\left[\mathrm{OR}_{\mathrm{aj}}=6,6\right.$ (IC 95\% 1,2 - 37,1)], $\mathrm{CD} 4+<500$ cél $/ \mathrm{mm}^{3}\left[\mathrm{OR}_{\mathrm{aj}}=3,8\right.$ (IC 95\% 1,1 - 13,6)], diagnóstico do HIV > 8 anos $\left[\mathrm{OR}_{\mathrm{aj}}=2,4\right.$ (IC 95\% 1,0 - 5,8)].

Conclusão: elevada prevalência de sífilis foi encontrada na população estudada e o uso de crack foi o principal fator identificado dentre os fatores associados. É necessário reforçar as intervenções para a redução do risco de transmissão sexual do HIV e da sífilis, com implementação de ações para o seu controle e estratégias de rastreamento, diagnóstico e tratamento precoces, evitando complicações e diminuindo a morbidade com melhoria da saúde sexual e reprodutiva.

Unitermos: sífilis; doenças sexualmente transmissíveis (DST); Aids; comportamentos de risco; mulheres.

\section{References}

1. WHO. World Health Organization: progress report, 2010. Disponivel em: http://www.who.int/reproductivehealth/topics/rtis/GlobalData_cs_ pregnancy.pdf

2. Dallabetta GA, Gerbase AC, Holmes KK. Problems, solutions, and challenges in syndromic management of sexually transmitted diseases. Sex Transm Infect. 1998;74(Suppl1):S1-11.

3. Mayaud P, Mabey D. Approaches to the control of sexually transmitted infections in developing countries: old problems and modern challenges. Sex Transm Infect. 2004;80(3):174-82.

4. Wasserheit JN. Epidemiological synergy: Interrelationships between human immunodeficiency virus infection and other sexually transmitted diseases. Sex Transm Dis. 1992;19(2):61-77.

5. Dickerson MC, Johnston J, Delea TE, White A, Andrews E. The causal role for genital ulcer disease as a risk factor for transmission of human immunodeficiency virus: an application of the Bradford Hill criteria. Sex Transm Dis. 1996;23(5):429-40.

6. Hutton-Rose N, Blythe C, Ogbonna C, McGrowder D. The prevalence of other sexually transmitted infections in confirmed HIV cases at a referral clinic in Jamaica. J R Soc Promot Health. 2008;128(5):242-7.

7. Lee HC, Ko NY, Chang CM, Liu SY, Ko WC. Trends in sexually transmitted diseases and risk behaviors among HIV-infected patients at an outpatient clinic in southern Taiwan. Sex Transm Dis. 2010;37(2):86-93.

8. Darrow WW, Echenberg DF, Jaffe HW, O 'Malley PM, Byers RH, Getchell $\mathrm{JP}$, et al. Risk factors for human immunodeficiency vírus (HIV) infection in homosexual men. Am J Public Health. 1987;77(4):479-83.

9. Stamm WE, Handsfield HH, Rompalo AM, Ashley RL, Roberts PL, Corey L. The association between genital ulcer disease and acquisition of HIV infection in homosexual men. JAMA. 1988;260(10):1429-33. 
10. Gray RH, Wawer MJ, Brookmeyer R, Sewankambo NK, Serwadda D, WabwireMangen F, et al. Probability of HIV-1 transmission per coital act in monogamous, heterosexual, HIV-1-discordant couples in Rakai, Uganda. Lancet. 2001;357(9263):1149-53.

11. WHO. Consultation on STD interventions for preventing HIV: what is the evidence? Geneva: UNAIDS/WHO, 2000

12. Nicoll A, Hamers FF. Are trends in HIV, gonorrhoea, and syphilis worsening in western Europe? BMJ. 2002;324(7349):1324-7.

13. Brasil. Ministério da Saúde - Secretaria de Vigilância em Saúde - Departamento de DST, Aids e Hepatites virais. Boletim Epidemiológico - Aids e DST. Ano $9, n^{\circ} 01$ até semana epidemiológica $26^{\mathrm{a}}$ - junho de 2012. Brasília (DF), 2012.

14. Flemming D, Wasserheit J. From epidemiological synergy to public health policy and practice: the contribution of other sexually transmitted diseases to sexual transmission of HIV infection. Sex Transm Inf. 1999;75(1):3-17.

15. Rodrigues EH, Abath FG. Sexually transmitted diseases in patients infected with HIV/AIDS in the State of Pernambuco, Brazil. Rev Soc Bras Med Trop. 2000;33(1):47-52.

16. Morimoto HK, Caterino-De-Araujo A, Morimoto AA, Reiche EM, Ueda LT, Matsuo T, et al. Seroprevalence and risk factors for human T cell lymphotropic virus type 1 and 2 infection in human immunodeficiency virus infected patients attending AIDS referral center health units in Londrina and other communities in Paraná Brazil. AIDS Res Hum Retrovir. 2005;21(4):256-62.

17. Travassos AG, Brites C, Netto EM, Fernandes SA, Rutherford GW, Queiroz CM. Prevalence of sexually transmitted infections among HIV-infected women in Brazil. Braz J Infect Dis. 2012;16(6):581-5.

18. Saxton J, Malyuta R, Semeneko I, Pilipenko T, Tereshenko R, Kulakovskaya I, et al. Previous reproductive history and post-natal family planning among HIV-infected women in Ukraine. Hum Reprod. 2010;25(9):2366-73.

19. Robertson MJ, Clark RA, Charlebois ED, Tulsky J, Long HL, Bangsberg DR, et al. HIV seroprevalence among homeless and marginally housed adults in San Francisco. Am J Public Health. 2004;94(7):1207-17.

20. Signorini DJ, Monteiro MC, De Sá CA, Sion FS, Neto HGL, Lima DP, et al. Prevalência da co-infecção HIV-sífilis em um hospital universitário da cidade do Rio de Janeiro no ano de 2005. Rev Soc Bras Med Trop. 2007;40(3):282-5.
21. Callegari FM, Pinto-Neto LF, Medeiros CJ, Scopel CB, Page K, Miranda AE. Syphilis and HIV co-infection in patients who attend an AIDS outpatient clinic in Vitoria, Brazil. AIDS Beh. 2014;18(Suppl 1):S104-9.

22. Zetola NM, Engelman J, Jensen TP, Klausner JD. Syphilis in the United States: an update for clinicians with na enphasis on HIV coinfection. Mayo Clin Proc. 2007;82(9):1091-1102.

23. Nuttbrock L, Rosemblum A, Magura S, McQuition HL, Joseph H. The association between cocaine use and HIV/STDs among soup kitchen attendees in New York City. J Acquir Immune Defic Syndr. 2000;25(1):8691.

24. Figueroa JP, Duncan J, Byfield L, Harvey K, Gebre Y, Hylton-Kong T, et al. A comprehensive response to the HIV/AIDS epidemic in Jamaica: a review of the past 20 years. West Indian Med J. 2008;57(6):562-76.

25. Hwang LY, Ross MW, Zack C, Rickman LBK, Holleman M. Prevalence of sexually transmitted infections and associated risk factors among populations of drug abusers. Clin Infect Dis. 2000;31(4):920-6.

26. Fonseca MG, Bastos FI. Twenty-five years of the AIDS epidemic in Brazil: principal epidemiological findings, 1980-2005. Cad Saúde Pública. 2007;23 (Suppl 3):S333-44.

27. Buchacz K, Patel P, Taylor M, Kerndt PR, Byers RH, Holmberg SD, et al. Syphilis increases HIV viral load and decreases CD4 cell counts in HIVinfected patients with new syphilis infectins. AIDS. 2004;18(15):2075-9.

28. Kofoed K, Gerstoft J, Mathiesen LR, Benfield T. Syphilis and human immunodeficiency virus (HIV)-1 coinfection: influence on CD4 T-cell count, HIV-1 viral load, and treatment response. Sex Transm Dis. 2006;33(3):143-8.

29. Kalichman SC, Pellowski J, Turner C. Prevalence of sexually transmitted coinfections in people living with HIV/AIDS: systematic review with implications for using HIV treatments for prevention. Sex Transm Infect. 2011;87(3):183-90.

30. Villela WV, Pinto VM. Atenção às DST em mulheres. In: Compromissos do governo brasileiro com a plataforma da conferência internacional sobre população e desenvolvimento: rumos para Cairo +20. Brasília (DF): Presidência da República. Secretaria Especial de Políticas para as Mulheres; 2010. p.159-79. 